\title{
Freedom from Violence, Full Access \\ to Resources, Equal Participation, \\ and Empowerment: The Relevance \\ of CEDAW for the Implementation \\ of the SDGs
}

\author{
Beate Rudolf
}

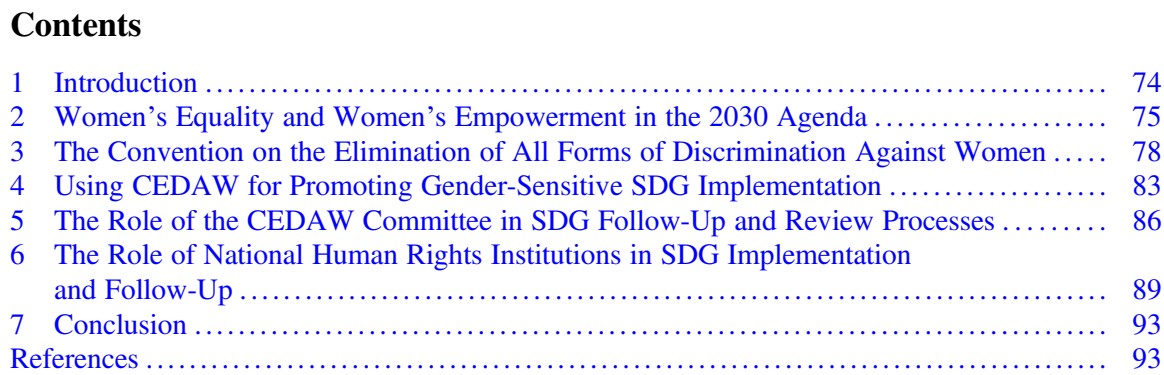

\begin{abstract}
The 2030 Agenda acknowledges the key role of gender equality and the empowerment of women for the implementation of the Sustainable Development Goals (SDGs) through Goal 5 as well as through the commitment to mainstreaming gender throughout all goals and in the implementation of the Agenda. The United Nations Convention on the Elimination of All Forms of Discrimination against Women (CEDAW) is the core international human rights treaty on women's equality in all fields, and it has produced a wealth of information on causes of discrimination against women, on gaps in implementing women's human rights that prevent their full and equal participation in all areas of life as well as on successful strategies and instruments to address the structural causes of gender-based discrimination. This article examines how the monitoring processes on CEDAW implementation can be
\end{abstract}

I would like to thank Julia Kercher, former Researcher and Policy Advisor at the German Institute for Human Rights, for her excellent preparation of the oral presentation at the Conference, which formed the starting point for the present contribution.

B. Rudolf $(\bowtie)$

German Institute for Human Rights, Berlin, Germany

e-mail: info@institut-fuer-menschenrechte.de

M. Kaltenborn et al. (eds.), Sustainable Development Goals and Human Rights, Interdisciplinary Studies in Human Rights 5,

https://doi.org/10.1007/978-3-030-30469-0_5 
used for promoting gender-sensitive SDG implementation. It also analyzes the possible synergies between the SDGs and CEDAW, in particular with respect to the national, regional, and global follow-up and review processes under the SDGs. As an example, the article looks into the role of National Human Rights Institutions in this regards.

\section{Introduction}

Thanks to UN Women and women's organizations from around the world, women's equality, especially their freedom from violence, their full access to resources, and equal participation in decision-making, as well as women's empowerment are part and parcel of the 2030 Agenda for Sustainable Development. ${ }^{1}$ From an early stage of the negotiations, UN Women had advocated for a stand-alone goal on women's equality. ${ }^{2}$ The aim was to have a goal that would go beyond the Gender Equality Goal in the Millennium Development Goals ${ }^{3}$ by addressing the structural causes of inequality. The result of the joint efforts is Goal 5 of the Sustainable Development Goals (SDGs), which reads:

\section{Goal 5. Achieve Gender Equality and Empower All Women and Girls}

5.1 End all forms of discrimination against all women and girls everywhere

5.2 Eliminate all forms of violence against all women and girls in the public and private spheres, including trafficking and sexual and other types of exploitation

5.3 Eliminate all harmful practices, such as child, early and forced marriage and female genital mutilation

5.4 Recognize and value unpaid care and domestic work through the provision of public services, infrastructure and social protection policies and the promotion of shared responsibility within the household and the family as nationally appropriate

5.5 Ensure women's full and effective participation and equal opportunities for leadership at all levels of decision-making in political, economic and public life

\footnotetext{
${ }^{1}$ For the role of women's organizations, see Sen (2019).

${ }^{2}$ UN Women, A Transformative Stand-alone Goal on Achieving Gender Equality, Women's Rights and Women's Empowerment: Imperatives and Key Components, New York 2013, http://www. unwomen.org/-/media/headquarters/attachments/sections/library/publications/2013/10/unwomen_ post2015_positionpaper_english_final_web\%20pdf.pdf?la=en\&vs $=1454 \quad$ (last accessed 15 July 2019).

${ }^{3}$ UN General Assembly Resolution "2015 World Summit Outcome," A/RES/60/1 (16 September 2005), paras. 58-59, later termed "Goal 3."
} 
5.6 Ensure universal access to sexual and reproductive health and reproductive rights as agreed in accordance with the Programme of Action of the International Conference on Population and Development and the Beijing Platform for Action and the outcome documents of their review conferences

5.a Undertake reforms to give women equal rights to economic resources, as well as access to ownership and control over land and other forms of property, financial services, inheritance and natural resources, in accordance with national laws

5.b Enhance the use of enabling technology, in particular information and communications technology, to promote the empowerment of women

5.c Adopt and strengthen sound policies and enforceable legislation for the promotion of gender equality and the empowerment of all women and girls at all levels". 4

Achieving women's full equality in all areas is also the object and purpose of the United Nations Convention on the Elimination of All Forms of Discrimination against Women (CEDAW), adopted in 1979. In this human rights treaty, often called the "Women's Rights Convention," the states acknowledged that discrimination against women is rooted in traditional gendered roles, and that discrimination holds women back from full participation in the political, social, economic, and cultural life of their countries and thus prevents them from bringing their potentialities to the service of their countries and humanity. ${ }^{5}$ Given the broad ratification of $\mathrm{CEDAW}^{6}$ and the vast experience of the CEDAW Committee, exploring the possible synergies between the SDGs and CEDAW is an idea that suggests itself so as to ensure that lessons learnt and information gathered under the Women's Rights Convention are made available for the implementation of the SDGs.

\section{Women's Equality and Women's Empowerment in the 2030 Agenda}

Women and their rights to equality, especially with respect to access to resources, equal public, economic, and social participation, as well as women's empowerment are not only one element of the Sustainable Development Goals (SDGs), but have an important place in the 2030 Agenda. In addition to gender equality and the empowerment of all women and girls being one of the 17 goals, many of the targets under

\footnotetext{
${ }^{4}$ UN General Assembly Resolution "Transforming our world: the 2030 Agenda for Sustainable Development”, A/RES/70/1 (25 September 2015).

${ }^{5}$ CEDAW, Preamble paras. 14 and 7, respectively.

${ }^{6}$ As of 15 July 2019, 189 states had ratified CEDAW.
} 
the other 16 goals specifically relate to the situation of women and girls. ${ }^{7}$ Moreover, the SDGs require systematic mainstreaming of a gender perspective in the implementation of the 2030 Agenda. $^{8}$ All three elements are brought together in paragraph 20 of UN General Assembly Resolution 70/1:

\begin{abstract}
Realizing gender equality and the empowerment of women and girls will make a crucial contribution to progress across all the Goals and targets. The achievement of full human potential and of sustainable development is not possible if one half of humanity continues to be denied its full human rights and opportunities. Women and girls must enjoy equal access to quality education, economic resources and political participation as well as equal opportunities with men and boys for employment, leadership and decision-making at all levels. We will work for a significant increase in investments to close the gender gap and strengthen support for institutions in relation to gender equality and the empowerment of women at the global, regional and national levels. All forms of discrimination and violence against women and girls will be eliminated, including through the engagement of men and boys. The systematic mainstreaming of a gender perspective in the implementation of the Agenda is crucial. $^{9}$
\end{abstract}

Consequently, the 2030 Agenda also provides that follow-up and review processes at all levels must be gender-sensitive. ${ }^{10}$

The reasons for the important place of women's equality in the SDGs are obvious. It is the present state of the world, pointedly described by the General Assembly: "Billions of our citizens continue to live in poverty and are denied a life of dignity. There are rising inequalities within and among countries. There are enormous disparities of opportunity, wealth and power. Gender inequality remains a key challenge." 11 Indeed, as the 2015 World Women's Report of the United Nations shows, considerable gender gaps to the disadvantage of women persist in areas such

\footnotetext{
${ }^{7}$ In particular: Target 2.2 (end hunger through ensuring secure and equal access to land for women), Target 4.3 (ensure inclusive quality education through equal access for all women and men to affordable and quality technical, vocational and tertiary education), Target 6.2 (ensure sanitation for all, paying special attention to the needs of women and girls), Target 8.5 (achieve full and productive employment and decent work for all women and men), Target 8.8 (protect labour rights, in particular for migrant women), Targets 11.2 and 11.7 (make cities inclusive and safe by expanding public transportation with special attention to the needs of women, and provide universal access to safe, inclusive and accessible, green and public spaces, in particular for women), and Target 13.b (combat climate change by raising capacity for effective climate change-related planning in LDCs, including focusing on women).

${ }^{8}$ UN General Assembly Resolution "Transforming our world: the 2030 Agenda for Sustainable Development”, A/RES/70/1 (25 September 2015), para. 20.

${ }^{9}$ UN General Assembly Resolution "Transforming our world: the 2030 Agenda for Sustainable Development”, A/RES/70/1 (25 September 2015), para. 20.

${ }^{10}$ UN General Assembly Resolution "Transforming our world: the 2030 Agenda for Sustainable Development", A/RES/70/1 (25 September 2015), para. 74 (e).

${ }^{11}$ UN General Assembly Resolution "Transforming our world: the 2030 Agenda for Sustainable Development”, A/RES/70/1 (25 September 2015), para. 14.
} 
as education, the labour market, as well as political power and decision-making. ${ }^{12}$ The gender pay gap and gendered family responsibilities contribute largely to gender disparities in poverty, which in turn is exacerbated if women are single and with dependent children. ${ }^{13}$ The gender gaps are all the more striking as men outnumber women worldwide by 62 million. ${ }^{14}$ All over the world, there are considerable differences between men and women in health trajectories throughout the life cycle, due to biological factors as well as gender-based inequality and gender norms. In the Global South, particular health risks exist for women in relation to pregnancy, childbirth, and sexually transmitted diseases, caused by underdeveloped health systems as well as gender-based obstacles. ${ }^{15}$ Violence against women is prevalent everywhere, with one third of the women worldwide having experiences physical and/or sexual violence by an intimate partner or sexual violence by a non-partner during their lives. ${ }^{16}$

For these reasons, the UN member states rightly call gender equality as being crucial to the realization of the SDGs. ${ }^{17}$ Only through realizing the three-pronged approach - a separate goal, a commitment to gender mainstreaming in the implementation of the SDGs, and gender-sensitive follow-up and review-can the UN member states fulfil their pledge that "no one will be left behind" ${ }^{18}$ — especially not women who make up half of the world's population and who are even more disadvantaged when their gender-based discrimination intersects with discrimination based on other grounds, such as belonging to an (ethnic, religious, language or sexual) minority or indigenous group, or because of their age, marital status, disability or migration background.

\footnotetext{
${ }^{12}$ UN Department of Economic and Social Affairs, The World's Women: Trends and Statistics, 2015, ST/ESA/STAT/SER.K/20 (2015), https://unstats.un.org/unsd/gender/downloads/ WorldsWomen2015_report.pdf (last accessed 15 July 2019), pp. xi-xii.

${ }^{13}$ UN Department of Economic and Social Affairs, The World's Women: Trends and Statistics, 2015, ST/ESA/STAT/SER.K/20 (2015), https://unstats.un.org/unsd/gender/downloads/ WorldsWomen2015_report.pdf (last accessed 15 July 2019), p. xiv.

${ }^{14}$ UN Department of Economic and Social Affairs, The World's Women: Trends and Statistics, 2015, ST/ESA/STAT/SER.K/20 (2015), https://unstats.un.org/unsd/gender/downloads/ WorldsWomen2015_report.pdf (last accessed 15 July 2019), p. ix.

${ }^{15}$ UN Department of Economic and Social Affairs, The World's Women: Trends and Statistics, 2015, ST/ESA/STAT/SER.K/20 (2015), https://unstats.un.org/unsd/gender/downloads/ WorldsWomen2015_report.pdf (last accessed 15 July 2019), p. x.

${ }^{16}$ UN Department of Economic and Social Affairs, The World's Women: Trends and Statistics, 2015, ST/ESA/STAT/SER.K/20 (2015), https://unstats.un.org/unsd/gender/downloads/ WorldsWomen2015_report.pdf (last accessed 15 July 2019), p. xiii.

${ }^{17}$ UN General Assembly Resolution "Transforming our world: the 2030 Agenda for Sustainable Development”, A/RES/70/1 (25 September 2015), para. 20.

${ }^{18}$ UN General Assembly Resolution "Transforming our world: the 2030 Agenda for Sustainable Development”, A/RES/70/1 (25 September 2015), preamble, 2nd para.
} 
It is noteworthy that the UN member states emphasize the importance of gender equality together with the empowerment of women. ${ }^{19}$ Indeed, the realization of the SDGs for women is inextricably linked with women's ability and opportunity to assert their fair share in the implementation of the 2030 Agenda. After all, it is their future, too, that is shaped through the SDG implementation processes. Therefore, women need to be agents of that change. The gender gaps between women and men as describes above are not simply the results of individual choices, but the results of gender-based power relations within all states of the world. They cause structural discrimination of women in the political, economic, and social fields, which can only be overcome by women's full and equal participation on all levels.

\section{The Convention on the Elimination of All Forms of Discrimination Against Women}

\section{A Globally Binding Standard}

Eradicating individual and structural discrimination of women in all areas-political, economic and social life-is the purpose of the Convention on the Elimination of All Forms of Discrimination against Women (CEDAW). It was adopted by the UN General Assembly in 1979, entered into force in 1981, and has been ratified by 189 states. $^{20}$ Until today, states, politicians, and scholars call into question the characterization of CEDAW as the global treaty on women's human rights because of the high number of reservations made by states upon ratification. ${ }^{21}$ However, a closer analysis reveals that the content and purposes of the reservations vary greatly. ${ }^{22}$ Many reservations have been removed or modified by now, reflecting changes in the understanding of the religious or cultural motivations (as well as of the reasons of domestic politics) that had prompted them upon ratification. ${ }^{23}$ Moreover, many states have not made reservations to other UN human rights treaties insofar as they guarantee substantive human rights and gender equality. On the contrary, in the Vienna World Conference and the Beijing World Conference on

\footnotetext{
${ }^{19}$ UN General Assembly Resolution "Transforming our world: the 2030 Agenda for Sustainable Development”, A/RES/70/1 (25 September 2015), para. 20.

${ }^{20}$ Ratification status as of 15 July 2019. Conspicuously missing are Iran, Somalia, Sudan, the US, and the Holy See.

${ }^{21}$ Tiefenbrun (2012), pp. 52-53. However, CRC has more reservations to substantive provisions, see Keller (2014), p. 311.

${ }^{22}$ For an analysis of the types of reservations see: Marsha A. Freeman, Reservations to CEDAW: An Analysis for UNICEF, UNICEF: New York December 2009, https://www.unicef.org/gender/ files/Reservations_to_CEDAW-an_Analysis_for_UNICEF.pdf (last accessed 15 July 2019), pp. 6-7. On the types of "Islamic reservations" see Mayer (1998), pp. 26-45. On the permissibility of the reservations see: Lijnzaad (1994).

${ }^{23}$ Connors (2012), pp. 591-594.
} 
Women, states have collectively proclaimed women's human rights as human rights, as being universal, inalienable, indivisible, and interrelated. ${ }^{24}$ Thus, the politically motivated attempts to downplay the importance of CEDAW as legally guaranteeing the universal human rights for all women, do not hold up to closer legal scrutiny.

It is noteworthy that, despite the existence of a reservation, the CEDAW Committee discusses the substantive issues covered by it with the state party concerned during the monitoring procedure under the Convention. It even addresses recommendations on the issues to them. This approach is based on the Committee's understanding that reservations are permissible so as to give a state time to adapt its legal and factual situation to the Convention, but not to opt out of parts of it permanently. ${ }^{25}$ Thus, the recommendations of the CEDAW Committee are intended to help the state achieve the aim of full realization of all Convention rights. This fact makes them useful for SDG implementation as well (see below at Sect. 4).

\section{Addressing the Root Causes of Discrimination}

CEDAW is unique among human rights treaties because it does not prohibit discrimination on the grounds of sex, but discrimination against women. This asymmetrical approach is due to the insight that there is a categorical difference between discrimination that women experience daily all over the world and discrimination against men: Discrimination against women is embedded in gendered societal power relations. They influence individual conduct, and more importantly, they also permeate structures, procedures, and institutions of the state as well as within society and the family. These power relations are upheld by gender stereotypes, which express societal expectations of women's (and men's) proper conduct and whose violations are sanctioned. They ensure a hierarchy between men and women and the domination of women by men. Thus, CEDAW reflects the understanding that discrimination against women is not based on sex-i.e. biological differences between women and men — but on gender — i.e. social constructions of what makes a woman and what makes a man. Its focus on gendered societal power relations is also the reason why CEDAW expressly obligates states to work towards overcoming gender stereotypes (Article 5).

\footnotetext{
${ }^{24}$ Vienna World Conference on Human Rights, Vienna Declaration and Programme of Action of 25 June 1993, A/CONF.157/23, para. 18 ("The human rights of women and of the girl-child are an inalienable, integral and indivisible part of universal human rights"); Fourth World Conference on Women, Beijing 4-15 September 1995, Final Declaration, para. 9, A/CONF./177/20/Rev.1 (1995) ("human rights of women and of the girl child as an inalienable, integral and indivisible part of all human rights and fundamental freedoms").

${ }^{25} \mathrm{By}$ this approach the Committee sidesteps the legal issues of the consequences of reservations that are incompatible with the object and purpose of CEDAW, and the question of whether it is competent to decide on the compatibility of a reservation with the Convention.
} 
By focusing on power relations CEDAW recognizes that women's full and equal enjoyment of all human rights requires a transformation of the distribution of power in the state, society, and the family. This understanding translates into a definition of discrimination that revolves around the exclusionary effect of discrimination (Article 1). ${ }^{26}$ Consequently, CEDAW expressly prohibits not only legal, but also factual discrimination (Article 2(f)). In addition, the state's obligation to eliminate discrimination not only covers discrimination by state actors, but by private actors as well (Article 2(e)). Finally, Article 4 permits temporary special measures aimed at accelerating de facto equality between women and men. These pillars make for the transformative potential of CEDAW.

Articles 7 to 16 expound the states' obligations in further detail so as to ensure equal participation, empowerment, and full access to resources. The provisions encompass women's equal participation in political and public life, both domestically (Article 7) and internationally (Article 8), as well as women's equality in becoming a citizen (Article 9). Equal access to education (Article 10) is the basis for women's empowerment. Access to resources is guaranteed through the right to equality in the labour market (Article 11), in health care (Article 12), and in all areas of economic, social and cultural life (Article 13). For many of these rights, full and equal legal capacity is a necessary prerequisite, which is, therefore, enshrined in Article 15. Full access to resources also hinges upon women's capacity to hold, inherit or otherwise acquire, keep and manage property, also during and after marriage, and to engage in salaried work or other economic activities. Article 16 lays down these rights for women. It also ensures women's self-determination with respect to marriage, viz. entering into marriage with a freely chosen spouse, the equal rights and responsibilities as a spouse and as a parent. Thus, CEDAW requires abolishing norms and practices by which husbands can hold power over wives. Lastly, CEDAW safeguards women's self-determination over their bodies, lives and future by expressly enshrining the "right to decide freely and responsibly on the number and spacing of their children" and to "access to the information, education and means to enable them to exercise these rights" (Article 16(1)(e)). Women's reproductive rights are reinforced by the guarantee of equal access to health care services related to family planning (Article 12(1)). The content of many of these rights has been spelt out in more detail by the CEDAW Committee through its

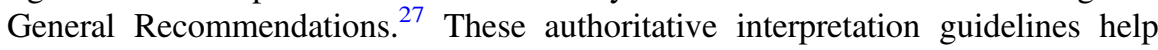

\footnotetext{
${ }^{26}$ Discrimination is defined as "any distinction, exclusion or restriction made on the basis of sex which has the effect or purpose of impairing or nullifying the recognition, enjoyment or exercise by women, irrespective of their marital status, on a basis of equality of men and women, of human rights and fundamental freedoms in the political, economic, social, cultural, civil or any other field." (emphasis added).

${ }^{27}$ Committee on the Rights of Persons with Disabilities (CRPD) and the Committee on the Elimination of All Forms of Discrimination against Women (CEDAW), Joint statement "Guaranteeing sexual and reproductive health and rights for all women, in particular women with disabilities”, 29 August 2018, INT/CEDAW/STA/8744 (2018).
} 
states develop their implementation policies and direct the monitoring under CEDAW's state reporting procedure.

It is noteworthy that CEDAW considers women in rural areas an important crosscutting issue deserving a specific provision (Article 14). This is an illustration of the Convention's approach to take into account the power relations in societies, as women in rural areas are often in particularly vulnerable situations due to the lack of public services and infrastructure, distance of state authorities, underdevelopment, or poverty. The Committee has devoted a General Recommendation to the provision. ${ }^{28}$ True to its power-sensitive approach, it also addressed issues of how to deal with the intersection of gender-based discrimination and other grounds of discrimination in a General Recommendation. ${ }^{29}$

What is conspicuously absent from the text of CEDAW is violence against women. When the Convention was drafted, violence against women was considered a question of social policy, not of human rights. It was only through the work of the CEDAW Committee, based on the findings from scholars and reports from women activists all over the world that this understanding changed. In 1993, the UN General Assembly recognized that "violence against women is a manifestation of historically unequal power relations between men and women, which have led to domination over and discrimination against women by men and to the prevention of the full advancement of women, and [...] violence against women is one of the crucial social mechanisms by which women are forced into a subordinate position compared with men." 30 This insight had led the CEDAW Committee, a year earlier, to adopt General Recommendation 19. ${ }^{31}$ It characterizes violence against women as a form of gender-based discrimination because it targets women disproportionately or because they are women. In 2017, the CEDAW Committee refined its understanding in General Recommendation 35. ${ }^{32}$ This document provides a comprehensive human rights based analysis of the forms and dimensions of violence against women, taking into account their diversity. It thus provides an excellent blueprint for monitoring states' compliance with their obligations under CEDAW to prevent, combat and redress violence against women effectively.

\footnotetext{
${ }^{28}$ CEDAW Committee, General recommendation No. 34 (2016) on the rights of rural women, CEDAW/C/GC/34, 7 March 2016.

${ }^{29}$ CEDAW Committee, General recommendation No. 28 on the core obligations of States parties under article 2 of the Convention on the Elimination of All Forms of Discrimination against Women, CEDAW/C/GC/28, 16 December 2010.

${ }^{30} \mathrm{UN}$ General Assembly Declaration on the Elimination of Violence against Women, A/RES/48/ 104 (20 December 1993), 6th preamble paragraph.

${ }^{31}$ CEDAW Committee, General recommendation No. 19: Violence against women, INT/CEDAW/ GEC/3731 (1992).

${ }^{32}$ CEDAW Committee, General recommendation No. 35 on gender based violence against women, updating general recommendation No. 19, CEDAW/C/GC/35, 27 July 2017.
} 


\section{A Blueprint for Comprehensive Action}

This overview shows that the full and effective elimination of the structural discrimination of women in the political, economic, and social fields are at the core of CEDAW. The human rights guaranteed by the Convention give women a legal basis for their demands, thus contributing to women's empowerment. As described above, these objectives are identical to those of the SDGs. Consequently, SDG implementation must tackle, as a priority, the structural causes of gender inequality, viz. unequal participation in private and public decision-making, violence against women, unpaid care work, and limited control over assets and property. ${ }^{33}$ In the words of the CEDAW Committee: "Realizing the full enjoyment of human rights by women is at the core of the 'transformative' impact of the Agenda 2030." 34 Using CEDAW and the insights gained through the monitoring process carried out by the CEDAW Committee should, therefore, guide the implementation of the SDGs.

Like all other UN human rights treaties, the implementation of CEDAW by the states parties is monitored by a committee of independent experts: the CEDAW Committee. It reviews the reports that every government must submit every four years after ratifying the Convention. The CEDAW Committee also receives information from non-governmental organizations and national human rights institutions, compares them with the state reports and discusses them with the government in interactive dialogues. This way, the CEDAW Committee has identified implementation gaps in which State action is necessary. The recommendations that the Committee addresses to each state party are public. ${ }^{35}$ States are expected to ensure follow-up of the recommendations with the participation of all relevant domestic actors. In this vein, CEDAW has led to, or contributed to national and subnational actions plans - human rights action plans, gender equality action plans, or specific plans such as action plans to combat violence against women. During the next reporting cycle before the CEDAW Committee, the state party is held to account on whether and what actions it has taken and their effects. Through this iterative process over several decades, the CEDAW Committee has been able to identify core women's human rights issues for almost each of the countries in the world, and is continuously evaluating the effectiveness of measures taken. SDG implementation should make use of this wealth of information.

The monitoring process under CEDAW also made it easier for states, non-state actors and international organizations to understand the linkages between different

\footnotetext{
${ }^{33}$ UN Women, A Transformative Stand-alone Goal on Achieving Gender Equality, Women's Rights and Women's Empowerment: Imperatives and Key Components, New York 2013, http://www. unwomen.org/-/media/headquarters/attachments/sections/library/publications/2013/10/unwomen_ post2015_positionpaper_english_final_web\%20pdf.pdf?la=en\&vs=1454 (last accessed 15 July 2019), pp. 2-3.

${ }^{34}$ CEDAW Committee, Submission to the Hugh Level Political Forum, 2016, INT/CEDAW/INF/ 8697 (2016), p. 4.

${ }^{35}$ They are available through the OHCHR Treaty Body Database at https://tbinternet.ohchr.org/ layouts/15/treatybodyexternal/TBSearch.aspx?Lang=en.
} 
women's human rights issues and across sectors. For example, gender-based stereotypes cause gender-based discrimination in society leading to many women focusing (or having to focus) on care work at the household level and to low access to economic resources and decision-making. This, in turn can lead to boys being favoured to pursue an education, resulting in a repetition of the cycle in the next generation. In order to break this cycle, it is not sufficient to address one element only; each of them has to be seen in its interlinkages. If, for example, women's economic participation is encouraged through training programmes or micro-credits, it is also necessary to ensure that family law does not give the husband the right to decide on financial assets in the family and that the law ensures all women's rights to conclude contracts. In addition, the state has to develop ways to ensure that family care work is not the sole responsibility of women. Such interlinkages are reflected in the country-specific recommendations of the CEDAW Committee. This is a further reason for using CEDAW within the SDG implementation.

\section{Using CEDAW for Promoting Gender-Sensitive SDG Implementation}

According to the 2030 Agenda, the primary responsibility for follow-up and review lies with the states. ${ }^{36}$ It envisages follow-up and review of the SDGs at the national, regional, and global level. ${ }^{37}$ At the global level, this is assured through the High Level Political Forum (HLPF), composed of the UN member states, the major groups identified by Agenda 21, and other stakeholders with a standing invitation to participate as observers in the General Assembly. ${ }^{38}$ Women constitute one of the major groups; they are represented by the Women's Major Group, a coalition of more than 600 organizations working to advance gender equality and women's human rights. The HLPF holds thematic discussions reviewing progress, e.g. by exchanging examples of good practice or specifying indicators, and they discuss the voluntary national reviews submitted by states. Regional follow-up and review varies, but in all regions the five regional UN Economic Commissions are involved. The design of follow-up and review at the national level forms is determined by each state, ideally after an inclusive participation process, with the support of the UN country teams, and that of other stakeholders, such as partner countries.

\footnotetext{
${ }^{36}$ UN General Assembly Resolution "Transforming our world: the 2030 Agenda for Sustainable Development," A/RES/70/1 (25 September 2015), para. 47.

${ }^{37}$ UN General Assembly Resolution "Transforming our world: the 2030 Agenda for Sustainable Development," A/RES/70/1 (25 September 2015), para. 47, and UN General Assembly Resolution "Follow-up and review of the 2030 Agenda for Sustainable Development at the global level," A/RES/70/299 (29 July 2016), paras. 2 and 10.

${ }^{38}$ UN General Assembly Resolution "Format and organizational aspects of the high-level political forum on sustainable development," A/RES/67/290 (23 August 2013), para. 14.
} 
It is striking that, despite the strong commitment to gender mainstreaming in the 2030 Agenda, ${ }^{39}$ the resolution on follow-up and review does contain any provision of how to ensure that this commitment is honoured. The participation of the Women's Major Group permits a gender perspective to be brought to the HLPF, ${ }^{40}$ but there is no obligation of the states to consider, let alone accept, proposals in this respect. Similarly, in his progress reports to the HLPF, the UN Secretary-General applies a gender perspective. ${ }^{41}$ Here again, it depends on the states whether they use this information in the thematic follow-up and review debates or in the debates on the voluntary national reviews. As show above (Sect. 3.3), the core concepts of CEDAW and the results of the international monitoring process under the Convention are a prime practical reason for using CEDAW to ensure a gender-sensitive implementation of the SDGs.

\section{Advantage CEDAW: Legally Binding Force}

In addition to the practical argument for having CEDAW guide states' SDG implementation, there is a strong legal argument that states are also legally bound to do so. The 2030 Agenda expressly provides for its implementation "consistent with the [...] obligations of states under international law", ${ }^{42}$ which includes human rights conventions such as CEDAW. This reflects a fundamental rule of international law: States must comply with their human rights obligations in whatever action they take. Consequently, states must make sure they do not violate women's human rights when implementing the SDGs. The 2030 Agenda goes even beyond this minimum by affirming, in clear and explicit language, the object and purpose of the CEDAW Convention, when acknowledging the need for realizing women's human rights to achieve the SDGs (see above, at Sect. 2). ${ }^{43}$ This congruence means that states must actively use the SDG implementation to realize women's human rights.

The legal force of CEDAW is of utmost practical relevance: Despite their high visibility and their present importance on the global level, the SDGs remain, in the

\footnotetext{
${ }^{39}$ UN General Assembly Resolution "Transforming our world: the 2030 Agenda for Sustainable Development," A/RES/70/1 (25 September 2015), paras. 20 and 74 (e).

${ }^{40}$ See, e.g., Women's Major Group, Paper for High Level Political Forum (2016). "Ensuring that no one is left behind": Listen to women for a change, 2016, https://wedo.org/wp-content/uploads/ 2016/07/10118WMG_HLPF_paper_2016_27April.pdf (last accessed 15 July 2019).

${ }^{41}$ See, e.g., UN Secretary-General, Special edition: progress towards the Sustainable Development Goals, E/2019/68 (2019).

${ }^{42}$ UN General Assembly Resolution "Transforming our world: the 2030 Agenda for Sustainable Development," A/RES/70/1 (25 September 2015), para. 18.

${ }^{43}$ UN General Assembly Resolution "Transforming our world: the 2030 Agenda for Sustainable Development," A/RES/70/1 (25 September 2015), para. 20, in particular; "The achievement of full human potential and of sustainable development is not possible if one half of humanity continues to be denied its full human rights and opportunities." (emphasis added).
} 
end, voluntary political commitments. ${ }^{44}$ As can be observed world-wide, translating the political commitment expressed at the global level into political action at the national level is not a given. When women's equal share in benefiting from the implementation of the SDGs in their respective country is at stake, gendered power relations will constitute powerful barriers, as they do in many political decisions. Through CEDAW, however, advocates for gender-justice in the sustainable development can bolster their demands through the legal obligation for all state actors to respect, protect and fulfill women's human rights, including by integrating these rights into the national legal systems, their political strategies, and by allocating sufficient budget for the implementation measures. Using CEDAW this way is particularly important for (state and international) actors in development cooperation, because it permits them to counter the criticism by powerful domestic actors that their call for women's rights means imposing "foreign values." Advocates for gender-justice in SDG implementation can point to CEDAW as the binding global standard to which the state has adhered by its own volition, and that, consequently, the state has to take serious the recommendations of the CEDAW Committee addressed to it.

\section{Concluding Observations and Recommendations as Baselines and Targets}

The concluding observations expressed by the CEDAW Committee at the end of a state reporting cycle provide a good overview of the main challenges that a state faces in the areas covered by CEDAW; and the CEDAW Committee's recommendations identify what needs to be done. The concluding observations are the outcome of a participatory analysis of the information provided by the state, civil society, national human rights institutions, and international organizations, as the CEDAW Committee holds (formal or informal) exchanges with all these actors. For this reason, they usually provide a description of the country situation that is wellfounded in quantitative and qualitative data. Thus, they can be used as a baseline, on the basis of which future progress can be measured. This is what happens in the next reporting cycle before the Committee, but it can also be used for the purposes of SDG implementation.

The level of detail of recommendations varies: Some of them formulate a target to reach, others spell out in detail which law or policy has to be adapted in which way so as to eliminate discrimination against women. In most cases, the recommendations leave room for the state authorities to develop a solution that is tailored to the

\footnotetext{
${ }^{44}$ This follows from the non-binding character of UN General Assembly resolutions. Moreover, UN General Assembly Resolution "Transforming our world: the 2030 Agenda for Sustainable Development," A/RES/70/1 (25 September 2015), para. 74 (a), expressly affirms that follow-up and review will be country-led.
} 
political, legal, and cultural specificities of the country. When the CEDAW Committee recommends a very specific measure to take, this may even be used as an indicator for the implementation of the human right concerned.

\section{The Role of the CEDAW Committee in SDG Follow-Up and Review Processes}

The CEDAW Committee shares its expertise with the High-Level Political Forum (HLPF) on a regular basis. In its contributions to the 2016 HLPF, the Committee reminded states that the prohibition of discrimination against women aims not only at formal equality (de iure equality), but at substantive equality (de facto equality). Furthermore, it reminds states of the intersectional discrimination that women experience worldwide, and as it is concerned that "the main gap between the Agenda 2030 and the CEDAW standards concerns sexual and reproductive health and rights (SDG Target 5.6), it called upon the states to ensure CEDAW-compliant SDG implementation in this respect. ${ }^{45}$

In its submission to the 2017 HLPF session, ${ }^{46}$ the CEDAW Committee emphasizes that violence against women has not diminished, including in the most developed countries. On equal participation in public life, the Committee's analyses show that positive trends remain limited in a number of ways: Participation of women in decision-making positions in all sectors-parliament, government, public service, private sector, academia - peaks at levels well under parity. Even where women are represented, this representation does not always translate into actual political power. That means, for instance, that if women head government ministries, those will often be the least powerful governmental departments. On access to resources and economic empowerment, the CEDAW Committee acknowledges that women are gaining more access to the labour market, but it highlights that when women are employed, they are more likely to occupy jobs that are insecure, hazardous, poorly paid, and not covered by social protection. These considerations illustrate the need for qualitative indicators in addition to quantitative ones.

For its contribution to the $2018 \mathrm{HLPF},{ }^{47}$ the CEDAW Committee uses its general recommendations and results from the state reporting procedure so as to highlight its specific concerns with respect to the Goals discussed at that session: Goal 4 (education), Goal 13 (climate change), and Goal 16 (access to justice).

\footnotetext{
${ }^{45}$ CEDAW, Submission to the 2016 High-Level Political Forum (2016), https://tbinternet.ohchr. org/Treaties/CEDAW/Shared\%20Documents/1_Global/INT_CEDAW_INF_8697_E.pdf (last accessed 15 July 2019), pp. 2, 3, and 4-5, respectively.

${ }^{46}$ CEDAW, Submission to the 2017 High-Level Political Forum (2017), http://www.ohchr.org/ Documents/HRBodies/CEDAW/CEDAW_HLPF17_28.04.2017.pdf (last accessed 15 July 2019).

${ }^{47}$ CEDAW, Submission to the 2018 High-Level Political Forum (27 April 2018), https://tbinternet. ohchr.org/Treaties/CEDAW/Shared\%20Documents/1_Global/INT_CEDAW_INF_8699_E.pdf (last accessed 15 July 2019).
} 
The CEDAW Committee not only shares its expertise with the HLPF for its thematic reviews. It also brings the SDGs into its interactive dialogues with governments. In its recommendations to Belarus, ${ }^{48}$ Burundi, ${ }^{49}$ Micronesia, ${ }^{50}$ and Antigua and Barbuda, ${ }^{51}$ for example, the Committee made very specific suggestions on how the government could address SDG targets 5.1 on discrimination against women; target 5.2 on violence against women; target 4.5 on educational disparities; and targets 3.1 and 3.7 on maternal mortality and sexual and reproductive health. Other recommendations refer to target 5(c) on sound policies and enforceable legislation for the promotion of gender equality by spelling out necessary content of an envisaged national action plan; to target 5.5 on women's equal participation in political and public life; or to target 8.5 (full employment and decent work for women) through an employment policy that includes temporary special measures and to increase women's recruitment by employers and through food subsidies, maternity allowances, and loans for women in the informal sector. ${ }^{52}$ In addition, the CEDAW Committee now formulates a standard recommendation on the national SDG implementation process to ensure a gender perspective, ${ }^{53}$ and even adds more specific procedural recommendations, such as mainstreaming the monitoring of its own recommendations into the State party's realization of the SDGs. ${ }^{54}$

\footnotetext{
${ }^{48} \mathrm{CEDAW}$, Concluding Observations on the eighth periodic report of Belarus, CEDAW/CO/BLR/ CO/8 (2016), paras. 23, 52.

${ }^{49} \mathrm{CEDAW}$, Concluding Observations on the combined fifth and sixth periodic reports of Burundi, CEDAW/C/BDI/CO/5-6 (2016), paras. 13, 29, 35, 39.

${ }^{50} \mathrm{CEDAW}$, Concluding Observations on the combined initial to third periodic reports of the Federated States of Micronesia, CEDAW/C/FSM/CO/1-3 (2016), paras. 13, 33, 37.

${ }^{51} \mathrm{CEDAW}$, Concluding Observations on the combined fourth to seventh periodic report of Antigua and Barbuda, CEDAW/C/ATG/CO/4-7 (2019), paras. 14, 28, 39.

${ }^{52} \mathrm{CEDAW}$, Concluding Observations on the seventh periodic report of Angola, CEDAW/C/AGO/ $\mathrm{CO} / 7$ (2019), paras. 16, 32, and 38, respectively.

${ }^{53} \mathrm{CEDAW}$, Concluding Observations on the combined fifth and sixth periodic reports of Burundi, CEDAW/C/BDI/CO/5-6 (2016), para. 55; CEDAW; Concluding Observations on the combined fourth to seventh periodic report of Antigua and Barbuda, CEDAW/C/ATG/CO/4-7 (2019), para. 7; CEDAW, Concluding observations on the fourth periodic report of Botswana, CEDAW/C/BWA/ $\mathrm{CO} / 4$ (2019), para. 7; CEDAW, Concluding Observations on the ninth periodic report of Colombia, CEDAW/C/COL/CO/9 (2019), para. 7; CEDAW; Concluding Observations on the eighth periodic report of Ethiopia, CEDAW/C/ETH/CO/8 (2019), para. 7; CEDAW, Concluding Observations on the fourth periodic report of Serbia, CEDAW/C/SRB/CO/4 (2019), para. 7; CEDAW, Concluding Observations on the eighth periodic report of the United Kingdom of Great Britain and Northern Ireland, CEDAW/C/GBR/CO/8 (2019), para. 7. For the initial version see CEDAW (2016), Concluding Observations on the eighth periodic report of Belarus, CEDAW/CO/BLR/CO/ 8 (2016), para. 52.

${ }^{54} \mathrm{CEDAW}$, Concluding Observations on the fourth periodic report of Serbia, CEDAW/C/SRB/CO/ 4 (2019), para. 10.
} 
Moreover, the CEDAW Committee also shares its expertise to help develop global SDG indicators for which methodologies and data are still missing. ${ }^{55}$ For this purpose, it is engaging with UN Women and the Office of the High Commissioner for Human Rights. In an early position paper, the three entities presented suggestions for indicators and identified which existing UN bodies or entities could serve as monitoring agencies. ${ }^{56}$ Nevertheless, the latest version of the United Nations Minimum Set of Gender Indicators, adopted by the United Nations Statistical Commission in 2018, barely reflects a human rights approach. ${ }^{57}$ In contrast, the expert group that developed indicators on Goals 10, 13, and 16 for the 2019 HLPF, refers, in passing, to states' obligations under CEDAW and lists some general recommendations of the CEDAW Committee among its resources. ${ }^{58}$ However, the focus of all these debates remains on quantitative data. Even if the process of developing human rights indicators for the various human rights treaties is still ongoing at the UN, it is clear that quantitative measuring has to be accompanied by qualitative data if the measuring exercise is to produce not only a picture of the factual situation, but also to permit evaluating whether there is room for bringing about better results in the future. With respect to CEDAW, there are proposals for qualitative indicators building on the CEDAW Committee's interpretation of the Convention, e.g. legislative indicators. ${ }^{59}$ These could also be used in monitoring SDG implementation.

\footnotetext{
${ }^{55}$ The UN Statistical Commission calls these indicators "Tier III" indicators (differentiating them from Tier I and Tier II indicators for which methodologies and/or data do exist), https://unstats.un. org/sdgs/iaeg-sdgs/tier-classification/ (last accessed 15 July 2019).

${ }^{56}$ UN Women, Monitoring Gender Equality and the Empowerment of Women and Girls in the 2030 Agenda for Sustainable Development, New York September 2015, http://www.unwomen.org/-/ media/headquarters/attachments/sections/library/publications/2015/indicatorpaper-en-final.pdf? la $=$ en\&vs $=212$ (last accessed on 15 July 2019).

${ }^{57}$ United Nations Statistics Division, The United Nations Minimum Set of Gender Indicators, 30 April 2019, https://genderstats.un.org/files/Minimum\%20Set\%20indicators\%202018.11.1\% 20web.pdf (last accessed 15 July 2019). Note that under the heading "Human rights of women and girl children", the Minimum Set only comprises indicators related to violence against women.

${ }^{58}$ Expert Group Meeting, Tackling global challenges to equality and inclusion through the genderresponsive implementation of the 2030 Agenda for Sustainable Development: Spotlight on SDGs 10, 13 and 16, Vienna, 27-28 February 2019, Annex I, p. 34, published by UN Climate Change, UNODC, and UN Women, 2019, https://sustainabledevelopment.un.org/content/documents/ 23808EGMViennaFin.pdf. (last accessed 15 July 2019), p. 14, 27, and 50.

${ }^{59}$ International Knowledge Network of Women in Politics (joint project of the International Institute for Democracy and Electoral Assistance (IDEA), the Inter-Parliamentary Union (IPU), the United Nations Development Programme (UNDP), and the United Nations Entity for Gender Equality and the Empowerment of Women (UN Women), CEDAW Legislative Compliance Indicators, without date, http://iknowpolitics.org/sites/default/files/indicators_chapter.pdf (last accessed on 15 July 2019).
} 


\section{The Role of National Human Rights Institutions in SDG Implementation and Follow-Up}

CEDAW will only guide the implementation of the SDGs if domestic actors and the international community push for this approach. An institutional actor whose mandate is to hold the state to its human rights obligations and to help it meet these obligations are National Human Rights Institutions (NHRIs).

NHRIs are independent public bodies with a broad mandate to protect and promote all human rights in their respective countries. They exist in more than 110 states worldwide. Their mandate and the criteria for independence are outlined in the Paris Principles, adopted by the UN General Assembly. ${ }^{60}$ Each NHRI's compliance with the Paris Principles is regularly reviewed through an accreditation procedure carried out by the global network of NHRIs, the Global Alliance of National Human Rights Institutions (GANHRI), under the auspices of the UN Office of the High Commissioner for Human Rights. ${ }^{61}$ NHRIs advise their governments and parliaments, they monitor their state's compliance with its human rights obligations, a lot of them can carry out investigations and bring cases to courts. Many NHRIs have an ombuds function or a complaint mechanism, through which people can submit their individual cases of alleged human rights violations. NHRIs are expected to engage with international human rights mechanisms so as to build a bridge between the international and the domestic levels and thus "bring human rights home." Thus, NHRIs can collect valuable information, they are experts in understanding international human rights and their implementation, and they hold governments to account. All these powers can be used with respect to CEDAWcompliant SDG implementation. ${ }^{62}$

Immediately after the adoption of the 2030 Agenda, NHRIs adopted the Mérida Declaration at their tri-annual global conference, and encouraged each other to contributing to the follow-up and review of the SDGs in a human rights compliant way. ${ }^{63}$ In particular, they recommended action on the country level and at the global

\footnotetext{
${ }^{60} \mathrm{UN}$ General Assembly Resolution "National Institutions for the promotion and protection of human rights," A/RES/48/134 (20 December 1993), Annex.

${ }^{61}$ For details of this procedure, see: GANHRI, A Practical Guide to the Work of the Sub-Committee on Accreditation, Geneva 2018, https://nhri.ohchr.org/EN/AboutUs/GANHRIAccreditation/Docu ments/GANHRI\%20Manual_online(1).pdf (last accessed 15 July 2019).

${ }^{62}$ See also: Stephen L.B. Jensen, Allison Corkery, Kate Donald, Realizing Rights through the Sustainable Development Goals: The Role Of National Human Rights Institutions, Danish Institute for Human Rights, June 2015, pp. 4-6, https://www.humanrights.dk/files/media/dokumenter/ udgivelser/research/nhri_briefingpaper_may2015.pdf (last accessed 15 July 2019).

${ }^{63}$ GANHRI, Mérida Declaration-The Role of National Human Rights Institutions in implementing the 2030 Agenda for Sustainable Development, 10 October 2015, https://nhri. ohchr.org/EN/ICC/InternationalConference/12IC/Background\%20Information/Merida\%20Declara tion\%20FINAL.pdf (last accessed 15 July 2019), para. 17.
} 
level, as well as cooperation between NHRIs, especially through their global and four regional networks to strengthen the capacities of all NHRIs in this respect. The UN Human Rights Council expressly welcomed this approach of NHRIs, and encouraged NHRIs to implement it. ${ }^{64}$

At country level, NHRIs can provide advice on a human rights-based approach to implementation and measurement of the SDGs. This includes assessing the impact of laws, policies, programmes, national development plans, administrative practices and budgets from the perspective of the realization of all human rights for all. On a practical level, this means that NHRIs can promote national targets, benchmarks and indicators that take into account the respective country's human rights challenges and obligations when governments develop or revise national SDG implementation plans. These targets, benchmarks and indicators should be based on the human rights treaties ratified by the state, such as CEDAW, and the concluding observations of the respective treaty body, such as the CEDAW Committee. Germany's NHRI, the German Institute for Human Rights, produced a synopsis of the SDGs and the recommendations addressed to the state by the UN treaty bodies. ${ }^{65}$ As the revised national sustainability strategy merely discussed violence against women, but did not measure it, ${ }^{66}$ the German Institute for Human Rights stressed the need to include an indicator that measures the implementation of the Council of Europe Convention on Violence against Women, the so-called Istanbul Convention, which the CEDAW Committee had also emphasized in its recommendations to Germany. The next revision of the German Sustainable Development Strategy saw the announcement of a programme of action on the implementation of that Convention, while still falling short of including an indicator in this respect. ${ }^{67}$

\footnotetext{
${ }^{64}$ UN Human Rights Council, Resolution 39/17 of 28 September 2018 (A/HRC/RES/39/17).

${ }^{65}$ German Institute for Human Rights, Sind die SDGs für Deutschland relevant, Annex, September 2015, https://www.institut-fuer-menschenrechte.de/fileadmin/user_upload/Publikationen/Weitere_ Publikationen/Sind_die_SDGs_fuer_Deutschland_relevant.pdf; English summary in: German Institute for Human Rights, Are the SDGs relevant for Germany?, October 2015, https://www. institut-fuer-menschenrechte.de/fileadmin/user_upload/Publikationen/Weitere_Publikationen/Are_ the_SDGs_relevant_for_Germany.pdf (both last accessed 15 July 2019).

${ }^{66}$ German Federal Government, German Sustainable Development Strategy. New Edition 2016 (11 January 2017), https://www.bundesregierung.de/resource/blob/998220/455740/ 7d1716e5d5576bec62c9d16ca908e80e/2017-06-20-langfassung-n-en-data.pdf?download=1 (last accessed 15 July 2019), p. 96.

${ }^{67}$ Bundesregierung, Deutsche Nachhaltigkeitsstrategie. Neuauflage 2018 (German Federal Government, German Sustainable Development Strategy. Revised Edition 2018) (7 November 2018), pp. 33, 42-45, English version not yet available), https://www.bundesregierung.de/resource/blob/ 975292/1559082/a9795692a667605f652981aa9b6cab51/deutsche-nachhaltigkeitsstrategieaktualisierung-2018-download-bpa-data.pdf?download=1 (last accessed 15 July 2019).
} 
When reviewing policy options and their potential effects, NHRIs can conduct human rights impact assessments, for example to help the government decide on a policy to spur economic growth that will best promote decent work and fair pay for women. In Germany, the NHRI, together with civil society organizations, successfully advocated for including human rights in the national definition of sustainability, which is used to conduct impact assessments on new laws and regulations. ${ }^{68}$

National Human Rights Institutions can also advise their respective governments on how to establish national SDG monitoring mechanisms that are truly participatory and that ensure accountability of the State to its people. This can include a transparent process for civil society to share data and their own analyses, when the national SDG implementation plan is reviewed and adjusted.

At the global level, when their country presents its voluntary national review at the High-Level Political Forum, National Human Rights Institutions can share their own evaluation, and they can encourage civil society to prepare alternative reports, as the Women's Major Group recommends. ${ }^{69}$ In addition, NHRIs can provide valuable information on the general obstacles to transparent and participatory SDG implementation. For this reason, GANHRI annually published a report on the status of civil society space in the states under voluntary national review, based on the information provided by the NHRIs concerned. ${ }^{70}$ NHRIs have more to contribute, including on women's human rights, as they committed to increase work in this field

\footnotetext{
${ }^{68}$ Bundesregierung, Deutsche Nachhaltigkeitsstrategie. Neuauflage 2018 (German Federal Government, German Sustainable Development Strategy. Revised Edition 2018) (7 November 2018), pp. 33, 42-45, English version not yet available), https://www.bundesregierung.de/resource/blob/ 975292/1559082/a9795692a667605f652981aa9b6cab51/deutsche-nachhaltigkeitsstrategieaktualisierung-2018-download-bpa-data.pdf?download=1 (last accessed 15 July 2019), p. 51.

${ }^{69}$ Women's Major Group, Recommendations from the Women's Major Group on engaging with the Voluntary National Review Process, 2017, http://www.womenmajorgroup.org/wp-content/ uploads/2017/05/WMG_Info_Note_Final_2017.pdf (last accessed 15 July 2019).

${ }^{70}$ GANHRI, Protecting and enlarging the space for public debates and participation of all civil society actors for the implementation of the SDGs and human rights. Background Paper (for HLPF 2016), 12 July 2016, http://nhri.ohchr.org/EN/News/Documents/GANHRI-BackgroundPaper -HLPF16-ShrinkingSpace_publ.com.pdf; GANHRI, Protecting and enlarging the space for public debates and participation of all civil society actor for the implementation of the SDGs and human rights. 2nd Background Paper (for HLPF 2017), July 2017, https://nhri.ohchr.org/EN/News/Docu ments/20170709_GANHRI-BackgroundPaper\%20-HLPF17-ShrinkingSpace_final. pdf\#search=shrinking\%20space; GANHRI, Space for Civil Society Participation in SDG Implementation. 3rd Background Paper (for HLPF 2018), July 2018 (all last accessed on 15 July 2019).
} 
in their Amman Declaration of 2012. ${ }^{71}$ The work of NHRIs in the area of women's human rights is reflected in their parallel reports to the CEDAW Committee in the state reporting procedure. Moreover, GANHRI has collected information from NHRIs on specific, CEDAW- and SDG-related themes, such as economic participation of women, ${ }^{72}$ the human rights of women in rural areas, ${ }^{73}$ and violence against women. $^{74}$

The UN General Assembly encouraged National Human Rights Institutions explicitly to participate and contribute to the deliberations on the 2030 Agenda. $^{75}$ However, NHRI participation is severely limited as NHRIs and their global and regional networks do not constitute a major group or other stakeholder (see above at Sect. 4). The UN bodies are still to heed the call of the General Assembly to extend NHRIs' participation rights. ${ }^{76}$ An invitation by the President of the General Assembly would make the wealth of information from NHRIs available to the international community for a better, CEDAW-compliant and gender-responsive implementation of the 2030 Agenda.

\footnotetext{
${ }^{71}$ ICC - International Coordinating Committee of National Human Rights Institutions (today: Global Alliance of National Human Rights Institutions (GANHRI), Amman Declaration and Program of Action, 7 November 2012, https://nhri.ohchr.org/EN/ICC/InternationalConference/ 11IC/Background\%20Information/Amman\%20PoA\%20FINAL\%20-\%20EN.pdf (last accessed 15 July 2019).

${ }^{72}$ Asia-Pacific Forum (APF) \& Global Alliance of National Human Rights Institutions (GANHRI), The Role of National Human Rights Institutions in Promoting and Protecting Women's Economic Participation in the Changing World of Work, Concept note presented at the 61st session of the Commission on the Status of Women 2017, https://nhri.ohchr.org/EN/Themes/WomenRights/Com mission $\% 20$ on $\% 20$ the $\% 20$ Status\%20of $\% 20$ Women/CSW_61_The $\% 20$ role $\% 20$ of $\% 20$ NHRIs $\%$ 20in\%20Promoting $\% 20$ and $\% 20$ Protecting $\% 20$ Women $\%$ E2\%80\%99s\%20Economic\%20Participa tion\%20in\%20the\%20Changing\%20World\%20of\%20Work.pdf (last accessed 15 July 2019).

${ }^{73}$ Global Alliance of National Human Rights Institutions (GANHRI) \& Asia Pacific Forum (APF), The Role of National Human Rights Institutions in promoting gender equality and the empowerment of women and girls living in rural areas, Report presented at the 62nd session of the Commission on the Status of Women 2018, https://nhri.ohchr.org/EN/Themes/WomenRights/Com mission\%20n\%20the $\% 20$ Status\%20 of $\% 20$ Women/GANHRI-APF\%20report\%20n $\% 20$ the $\%$ 20Role $\% 20$ of $\% 20$ NHRIs $\% 20$ in $\% 20$ promoting $\% 20$ gender $\% 20$ equality $\% 20$ and $\% 20$ the $\%$ 20empowerment $\% 20$ of $\% 20$ women $\% 20$ and $\% 20$ girls $\% 20$ in\%20rural\%20areas.pdf (last accessed 15 July 2019).

${ }^{74}$ Global Alliance of National Human Rights Institutions (GANHRI), Preventing and Eliminating All Forms of Violence against Women and Girls: The Role of National Human Rights Institutions A contribution to the review and priority themes of CSW63, Geneva 2019, https://nhri.ohchr.org/EN/ Themes/WomenRights/Commission\%20on\%20the\%20Status\%20of\%20Women\%2062/DIMR_ GANHRI\%20CSW\%20Report_final\%20BF.pdf (last accessed 15 July 2019).

${ }^{75}$ UN General Assembly Resolution "National institutions for the promotion and protection of human rights", A/RES//70/163 (17 December 2015), paras. 15.

${ }^{76}$ UN General Assembly Resolution "National institutions for the promotion and protection of human rights", A/RES//70/163 (17 December 2015), paras. 16.
} 


\section{Conclusion}

The transformative potential of the Sustainable Development Goals hinges on women's equal participation, their empowerment, equal access to resources, and freedom from gender-based violence. Gender-based discrimination and exclusion of women is deeply entrenched in all societies and state structures worldwide. Through the work of the CEDAW Committee, CEDAW provides an invaluable resource for identifying the core challenges in every state, and the Committee's concluding observations and recommendations provide a baseline for future evaluation and specific targets. The CEDAW Committee, as well as National Human Rights Institutions, have been using this qualitative information so as to achieve a CEDAW-compliant and gender-responsive implementation of the SDGs. CEDAW and the 2030 Agenda are mutually reinforcing: CEDAW brings legally binding force, detailed obligations, and its own monitoring mechanism, which it applies for the SDGs as well. The SDGs bring and renew the political commitment and the international cooperation necessary to ensure that the future development of the world is sustainable and does not leave behind half of humanity.

\section{References}

Connors J (2012) Article 28 CEDAW. In: Freeman MA, Chinkin C, Rudolf B (eds) The UN Convention on the elimination of all forms of discrimination against women: a commentary. Oxford University Press, Oxford, pp 565-595

Keller LM (2014) The impact of states parties' reservations to the Convention on the elimination of all forms of discrimination against women. Mich State Law Rev 2014(2):309-326

Lijnzaad L (1994) Reservations to United Nations human rights treaties: ratify and ruin? Brill/ Nijhoff, Leiden

Mayer AE (1998) Islamic reservations to human rights conventions. A critical assessment. RIMO. Recht van de Islam/Human Rights Islam 15:26-45

Sen G (2019) Gender equality and women's empowerment: feminist mobilization for the SDGs. Glob Policy 10(Supp. 1):28-37

Tiefenbrun SW (2012) Women's international and comparative human rights law. Carolina Academic Press, Durham

Beate Rudolf is Director of the German Institute for Human Rights (GIHR), the National Human Rights Institution of Germany (A-status accredited under the United Nations Paris Principles). From 2016 to 2019, she also chaired the Global Alliance of National Human Rights Institutions (GANHRI). Prior to her appointment to the GIHR, she was a junior professor for public law and equality law at the faculty of law of Freie Universität Berlin and director of the research project "Public International Law Standards for Governance in Weak and Failing States" within the Research Center "Governance in Areas of Limited Statehood". Her research focuses on human rights and legal principles on state structures under public international law, European law and German constitutional law. She was Vice-President of the European Women Lawyers Association (EWLA) and is a member of the ILA Committee on Feminism in International Law as well as an 
advisory member of the Committee on Public International and European Law of the German Women Lawyers' Association (djb). She is a co-editor of the international CEDAW Commentary published by Oxford University Press and was awarded the Margherita-von-Brentano-Award of Freie Universität Berlin for her outstanding academic and socio-political contribution to human rights, in particular women's human rights.

Open Access This chapter is licensed under the terms of the Creative Commons Attribution 4.0 International License (http://creativecommons.org/licenses/by/4.0/), which permits use, sharing, adaptation, distribution and reproduction in any medium or format, as long as you give appropriate credit to the original author(s) and the source, provide a link to the Creative Commons licence and indicate if changes were made.

The images or other third party material in this chapter are included in the chapter's Creative Commons licence, unless indicated otherwise in a credit line to the material. If material is not included in the chapter's Creative Commons licence and your intended use is not permitted by statutory regulation or exceeds the permitted use, you will need to obtain permission directly from the copyright holder. 